\title{
Siew New Disease Reports \\ First report of leaf blight caused by Alternaria longipes on oat in Turkey
}

H. Hekimhan ${ }^{1} *$, Y. Eğerci ${ }^{2}$ and A. Uysal-Morca ${ }^{3}$

\author{
${ }^{1}$ Aegean Agricultural Research Institute, PO Box 9, 35661 Menemen, Izmir, Turkey ; ${ }^{2}$ Plant Protection Research Institute, \\ Gençlik Cad. No: 6, 35040 Bornova, Izmir, Turkey ; ${ }^{3}$ Plant Protection Central Research Institute, FSM Bulvarı, 06172 \\ Yenimahalle, Ankara, Turkey \\ *E-mail: hakanhekimhan@hotmail.com
}

Received: 10 Jul 2020. Published: 29 Jul 2020. Keywords: Avena sativa, fungal plant disease

In May 2016, ovoid spots, brown in colour with yellow halos (Fig. 1) were observed on leaves of oat (Avena sativa) in two fields in the Foça and Menemen districts of İzmir, Turkey. These spots were initially on the lower leaves and then progressed to the upper leaves. Later, the spots coalesced and appeared as blights covering the leaf surface including the sheath (Figs. 2-3). The same symptoms were also observed on oat in both the original and new locations (Balıesir and Edirne) in 2017 and 2019. Disease incidence and severity ranged from $50-80 \%$ and $3-50 \%$, respectively.

Fourty leaf samples were collected from either diseased or healthy plants from the affected fields in Foça and Menemen in 2016. Plant tissues were cut into small pieces and exposed to $\mathrm{NaOCl}(2 \%)$ then, rinsed with sterile distilled water and transferred to potato dextrose agar. After incubation at $25^{\circ} \mathrm{C}$ for five days, fungal colonies similar in appearance developed. Four isolates were identified based on morphological characters and using the criteria of Woudenberg et al. (2013) and El-Alwany (2015). Colonies of the isolates were radial, greyish-dark green with dense airy mycelium. Conidiophores were light brown with few regular septa and mostly unbranched. Conidia were brown-ovoid or narrowly ellipsoid (25.2-48.5 $\times$ 5.8-15.5 $\mu \mathrm{m}$ ), sometimes solitary but usually in chains, with 4-6 transverse and 2 longitudinal septa. Morphological characterisation was confirmed by PCR with ITS-1 and ITS-4 (White et al.,1990). Sequences of the PCR product for the isolate were deposited in GenBank with the accession number MN067804. BLASTn analyses of the PCR product revealed $99.6 \%$ identity with reference sequences MK675101, MK659953, MH356770 and KY026585 in GenBank. ITS sequencing and morphological characteristics showed that the fungus is Alternaria longipes (Guo-yin et al., 2013).

Pathogenicity tests were conducted by spraying a spore suspension $\left(1 \times 10^{6}\right)$ of a seven-day-old culture of the isolates on oat plants (cv. Kahraman) and incubating at $24 \pm 2{ }^{\circ} \mathrm{C}$ with $85 \%$ relative humidity in climate rooms. In the control plants, only distilled water was sprayed. Eight days after incubation, similar symptoms like those observed in the field appeared on the inoculated plants (Fig. 4) while control plants did not show symptoms. Disease severity of the isolates ranged from 6 to $25 \%$ in inoculated plants. A. longipes was reisolated from the inoculated plants, fulfilling Koch's postulates.

To our knowledge, this is the first report of A. longipes causing leaf blight on oat in Turkey.

\section{References}

1. El-Alwany AM, 2015. Plant pathogenic Alternaria species in Libya. Open Access Library Journal 2, e1662. http://dx.doi.org/10.4236/oalib.1101662

2. Guo-Yin T, Zhi-Ling Y, Zhi-Lin Y, Shou-An Z, 2013. Morphological, molecular and pathogenic characterization of Alternaria longipes, the fungal pathogen causing leaf spot on Atractylodes macrocephala. African Journal of Microbiology Research 7, 2589-2595. http://dx.doi.org/10.5897/AJMR12.2091

3. White TJ, Bruns T, Lee S, Taylor J, 1990. Amplification and direct sequencing of fungal ribosomal RNA genes for phylogenetics. In: Innis MA, Gelfand DH, Sninsky JJ, White TJ, eds. PCR Protocols: A Guide to Methods and Applications. San Diego, CA, USA: Academic Press, 315-322.

http://dx.doi.org/10.1016/B978-0-12-372180-8.50042-1

4. Woudenberg JHC, Groenewald JZ, Binder M, Crous PW, 2013. Alternaria redefined. Studies in Mycology 75, 171-212. http://dx.doi.org/10.3114/sim0015

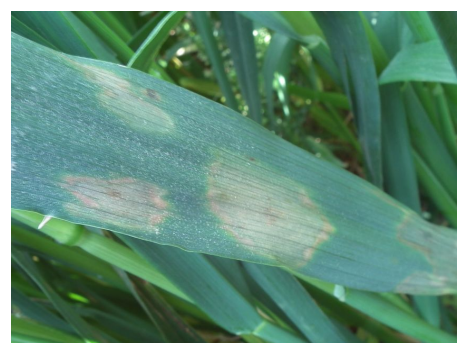

Figure 1

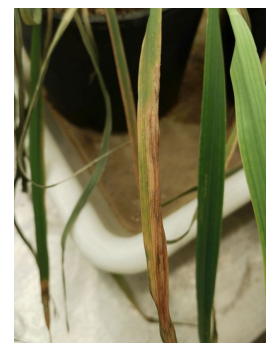

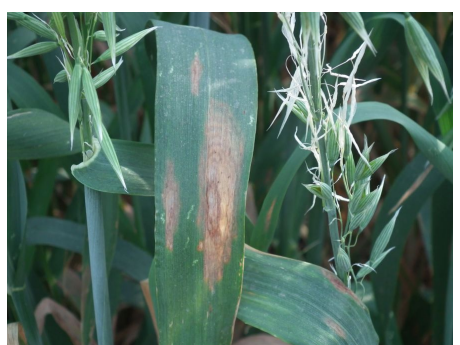

Figure 2

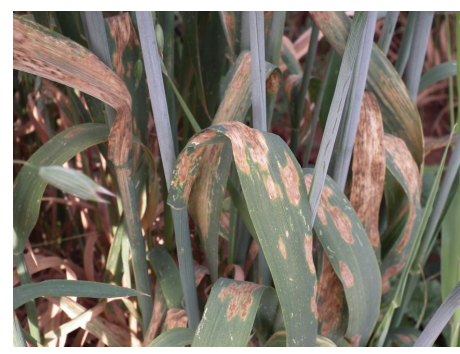

Figure 3

Figure 4

To cite this report: Hekimhan H, Eğerci Y, Uysal-Morca A, 2020. First report of leaf blight caused by Alternaria longipes on oat in Turkey. New Disease Reports 42, 3. http://dx.doi.org/10.5197/j.2044-0588.2020.042.003

(c) 2020 The Authors

This report was published on-line at www.ndrs.org.uk where high quality versions of the figures can be found. 